\title{
EVALUATION OF A PROGRAM OF PHYSICAL ACTIVITIES ADAPTED TO THE MORPHOLOGICAL, PHYSIOLOGICAL AND BODY COMPOSITION PARAMETERS OF OVERWEIGHT AND OBESE ADOLESCENTS OF THE LUKUNGA SPORTS CLUB OF KINSHASA, DEMOCRATIC REPUBLIC OF CONGO
}

\author{
Bofosa Linkoko Teddy, ${ }^{1}$ Kam Kampy Eric, ${ }^{2}$ Miangindula Mabenza Betty, ${ }^{1}$ \\ Njimbu Kampend Francois, ${ }^{2}$ Nkiama Ekisawa Constant ${ }^{1}$ \\ ${ }^{1}$ Kinesiology service, Physical medicine and rehabilitation, University clinics of Kinshasa, \\ University of Kinshasa, Democratic republic of Congo \\ ${ }^{2}$ Physiotherapy service, Physical medicine and rehabilitation, University clinics of Kinshasa, \\ University of Kinshasa, Democratic republic of Congo
}

Primljen/Received 04. 08. 2018. god.

Abstract: Objective. To study the effects of regular physical activity on the morphological, physiological and body composition parameters of overweight and obese adolescents.

Methods. We conducted an experimental study with30 adolescents divided in two according to their body mass index. The group 1 was composed of overweight subjects with a body mass index between $25-29.9 \mathrm{~kg} / \mathrm{m}^{2}$, and group 2 obese subjects with a body mass index $\geq 30 \mathrm{~kg} / \mathrm{m}^{2}$ subjected to a program of adapted physical activity associated with a low-calorie nutrition education low in cholesterol and in saturated fatty acids (bad fats), low-fat rich in vegetables, fruits and vitamins for a period of six months.

Results. This study reveals that after six months of intervention, overweight subjects significantly decreased waist circumference $(82.9 \pm 4.2 \mathrm{~cm}$ before versus $77.6 \pm$ $4.6 \mathrm{~cm}$ after $)$, heart rate $(86.8 \pm 3.6 \mathrm{beat} / \mathrm{min}$ before versus $81.4 \pm 3.8 \mathrm{beat} / \mathrm{min}$ after $)$, total fat $(32.2 \pm 1.8 \%$ before versus $27.2 \pm 1.5 \%$ after $)$, visceral fat $(16.6 \pm 2.3 \%$ before versus $11.1 \pm 2.5 \%$ after $)$, and decreased muscle (15.6 \pm $2.7 \%$ before versus $19.4 \pm 4.1 \%$ after), while obese subjects significantly decreased waist circumference $(88.9 \pm$ $6.2 \mathrm{~cm}$ before versus $85.8 \pm 5.9 \mathrm{~cm}$ after), visceral fat $(17.4 \pm 3.2 \%$ before versus $14.1 \pm 3.1 \%$ after), respiratory capacity $(61.1 \pm 2.7 \%$ before versus $65 \pm 2.1 \%)$. In addition this study reveals that overweight subjects compared to obese subjects more changed their waist circumference (77.6 $\pm 4.6 \mathrm{~cm}$ for overweight versus $85.8 \pm 5.9 \mathrm{~cm}$ for
Prihvaćen/Accepted 23. 09. 2018. god.

obese), body mass index $\left(24.9 \pm 4.1 \mathrm{~kg} / \mathrm{m}^{2}\right.$ for overweight versus $28.8 \pm 1.2 \mathrm{~kg} / \mathrm{m}^{2}$ for obese), heart rate $(81.4 \pm 3.8$ beat $/ \mathrm{min}$ for overweight versus $28.8 \pm 1.2$ beat $/ \mathrm{min}$ for obese), visceral fat (11.1 $\pm 2.5 \%$ for overweight versus $14.1 \pm 3.1 \%$ for obese), and muscle $(19.4 \pm 4.1 \%$ for overweight versus $17.1 \pm 2.1 \%$ ).

Conclusion. Obese adolescents have by means of regular activity significantly changed their morphological, physiological and body composition parameters of overweight and obese.

Key words: Adolescent, body composition, morphology, physiology, overweight, obesity.

\section{INTRODUCTION}

Overweight and obesity are now ranked fifth among global mortality risks. In addition, $44 \%$ of the burden of diabetes, $23 \%$ of the burden of ischemic heart disease and between $7 \%$ and $41 \%$ of the burden of some cancers can be attributed to them (1). Obesity has negative health consequences in childhood as well as in the long term.

In addition to a higher risk of obesity and noncommunicable diseases at a later age, children with other adverse effects such as breathing difficulties, increased risk of fractures, hypertension, early markers cardiovascular diseases, insulin resistance and psychological effects (2).

In 2005, noncommunicable diseases were estimated to cause nearly 35 million deaths worldwide, $80 \%$ of them in low- and middle-income countries (3). 
The progression of childhood obesity over the last decade is catastrophic. Current estimates suggest that the rate of obesity in developed countries is twice that of developing countries, in absolute numbers the prevalence is much higher in developing countries. The number of overweight / obese children in these countries is estimated at 35 million, compared to 8 million in developed countries (4).

In Africa, the number of overweight or obese children has almost doubled since 1990, from 5.4 million to 10.3 million (5).

In the Democratic Republic of Congo (DRC), its prevalence has doubled since 1980, it was estimated at $5.7 \%$ by a survey of the Ministry of Health conducted in Kinshasa in 2006. This survey focused on risk factors for noncommunicable diseases in Kinshasa, the World Health Organization (WHO) Ministry of Public Health $(6,7)$.

To prevent and minimize the complications of overweight and obesity in children and adolescents, the World Health Organization has developed strategies for management including physical activities and a diet.

The practice of physical activities in the Democratic Republic of Congo, tends to be neglected in our schools for pedagogical reasons including the lack of qualified teachers, lack of appropriate program and rigor in the application of the program in basic education, the lack of appropriate infrastructure or their assignment to other more lucrative activities for the school (party room, classroom or lack of awareness of the contribution of sport physical activity (SPA) in the prevention or treatment of obesity).

We have found that few studies conducted in our community (8) have evaluated the effects of physical activity only on psychological parameters.

However, none of these studies evaluated the effects of physicalactivity in adolescent subjects on the morphological, physiological and body composition parameters of obese adolescents. Therefore, with this study we aimed to fill this gap.

\section{MATERIAL AND METHODS \\ Nature and period of study}

We opted for the experimental method and conducted a longitudinal study that consisted in following the evolution of the morphological, physiological (cardiorespiratory) parameters and body composition of overweight and obese adolescents during the period from August 20, 2017 to January 20, 2018.

\section{Framework of the study}

The present study took place at the Lukunga Sports Club, CPA district in the city of Mbudi, city Kinshasa province, Democratic Republic of Congo served as a framework for the present study.

\section{Sample of the study}

Our target population was all overweight and obese teenagers practicing physical activities at the Lukunga sports club in Kinshasa.

Our study sample consisted of 19 overweight and 11 obese subjects. Inclusion criteria: to have freely accepted to participate in our study, being present on the day of the evaluation, tohave 12-17 of age, to be regular in practicing physical activities at the Lukunga sports club, not to have pathologies that are contraindicated for physical activity, and BMI $\geq 25 \mathrm{~kg} / \mathrm{m}^{2}$. Exclusion criteria: any overweight or obese teenager who has not met the inclusion criteria above.

\section{Variables of the study}

The variables used were the following:

- morphological

- Height (cm): It was assessed using a SECA branded toothy, the teenager in underwear, was measured standing, heel joints, head placed so that the line of vision is perpendicular to the body.

- Weight $(\mathrm{kg})$ : It was measured using a weight scale of SECA brand calibrated in kilograms $(\mathrm{kg})$ to $100 \mathrm{~g}$ near, the teenager was standing on the scale, head up, look towards the horizon with an undergarment.

The body mass index (BMI) of adolescents was calculated according to the formula: BMI: mass $(\mathrm{kg}) /$ Height (m). According to the World Health Organization (WHO) and the international Obesity Task Force $(13,14)$, overweight has been defined for BMI values between $25-29.9 \mathrm{~kg} / \mathrm{m}^{2}$, obesity when it was $\geq 30 \mathrm{~kg} / \mathrm{m}^{2}$.

- Waist circumference (WC) $(\mathrm{cm})$ : it was measured using a metric tape.

- Physiological

- Heart rate (HR) (bpm): it was taken using a stethoscope and stopwatch.

- Respiratory frequency (RF) (Cycle / min): it was taken using a stopwatch.

- Forced expiratory volume (FEV)per second (\%): It was evaluated using a Piko- 6 brand spirometer

- Body composition (\%)

The body composition was evaluated using an Omeron BF-511 scale impedance meter, it allowed us to evaluate the percentage of total fat (TF), percentage of visceral fat (VF) and percentage of muscle.

\section{Content of the program}

The content of our program was based on aerobic endurance exercises, stretching, coordination, gymnastic balance, and muscle building. This program of intervention in Physical Activities was practiced two ses- 
sions per week of 45 minutes at a moderate to severe intensity. To avoid monotony these different exercises were practiced with several variants. Nutritional education was composed of foods, hypocaloric low in cholesterol and saturated fatty acids (bad fats), low sodium rich in vegetables, fruits and vitamins.

\section{Statistical analysis}

The data collected was entered using the Microsoft Excel 2013 software and imported into SPSS software version 21.0 (Statiscal Package For Social Sciences). Quantitative variables were presented as mean \pm standard deviation and their extremes in the tables.

To verify the effects of exercise on nutritional status, we used we used the analysis of variance (ANOVA) to compare more than two means. The statistical test results used were interpreted at the significance level $\mathrm{p} \geq 0.05$ for statistical decision making.

\section{Ethical consideration}

All the parents of the children had consented in writing for the participation of their children in the study according to the declarations of Helsinki. The information collected from the children was kept confidential.

\section{RESULTS}

The results reported in Table 1 show a significant decrease in waist circumference, heart rate, visceral fat and an increase in muscle mass of overweight or obese subjects after the intervention program. However, these decreases or increases were much more observed in overweight subjects.

\section{DISCUSSION}

The aim of this study was to study the effects of aerobic-type regular physical activity and muscle building on the morphological, physiological and body composition of obese adolescents. It appears from this study that before the intervention program, no significant difference was observed between overweight and obese adolescents.

With regard to overweight adolescents taken in an isolated manner, this reveals that the latter have the mean weight, respiratory rate and forced expiratory volume per secondhave not been significantly modified, decreased their waist circumference by $-5.3 \mathrm{~cm}$. body mass of $-3.2 \mathrm{~kg} / \mathrm{m}^{2}$, heart rate of $-5.4 \mathrm{bpm}$, total fat of $-5 \%$, visceral fat $-5.5 \%$ but their muscle increased statistically significantly by +38 . That regular physical activity allows obese patients to significantly improve their morphological, physiological and body composition $(9,10,11)$. On the other hand, they are superior to those revealed by Bellow et al (10). In his analysis of 46 studies, where the average duration of exercise was 16.3 weeks demonstrated that the practice of physical exercises allows to modify the morphological state of the obese subjects. This is justified by the fact that our duration of study was superior to them.

Our results corroborate that of the literature, which emphasizes that moderate to high exercise for at least 8 weeks in overweight or obese subjects is effective in reducing abdominal fat. Numerous studies have confirmed the existence of an inverse relationship between the level of physical activity and waist circumference, the waist circumference / hip circumference, and the measurement of intra-abdominal adiposity by different techniques. medical imaging (12). These favorable effects and body modifications can occur even in the absence of significant weight loss $(12,13)$. Indeed, for the same body mass index (BMI), individuals with good physical fitness (fitness) have less subcutaneous abdominal fat and visceral fat than subjects with a low level of fitness $(12,14)$.

Training reduces resting heart rate (with no increase in maximum heart rate), increases myocardial mass (mainly left ventricle) and stroke volume, decreases cardiac muscle oxygen consumption, and improves ex-

Table 1. Comparison of the morphological, physiological and body composition means of the participants before and after the intervention program

\begin{tabular}{|c|c|c|c|c|c|}
\hline \multirow{3}{*}{ Parameters } & \multicolumn{2}{|c|}{ Before } & \multicolumn{3}{|c|}{ After } \\
\hline & Overweight & Obese & Overweight & Obese & ANOVA \\
\hline & $\mathrm{X} \pm \mathrm{SD}$ & $\mathrm{X} \pm \mathrm{SD}$ & $\mathrm{X} \pm \mathrm{SD}$ & $\mathrm{X} \pm \mathrm{SD}$ & $p$ value \\
\hline Weight $(\mathrm{kg})$ & $66.6 \pm 2.2$ & $66.8 \pm 2.3$ & $61.4 \pm 2.06$ & $62.7 \pm 1.5$ & 0.821 \\
\hline $\mathrm{WC}(\mathrm{cm})$ & $82.9 \pm 4.2^{*}$ & $88.9 \pm 6.2^{*}$ & $77.6 \pm 4.6^{*}$ & $85.8 \pm 5.9^{*}$ & 0.000 \\
\hline BMI $\left(\mathrm{kg} / \mathrm{m}^{2}\right)$ & $28.1 \pm 1.2$ & $31.8 \pm 1.5$ & $24.9 \pm 4.1$ & $28.8 \pm 1.2$ & 0.437 \\
\hline HR (beat/min) & $86.8 \pm 3.6^{*}$ & $89.4 \pm 5.1^{*}$ & $81.4 \pm 3.8^{*}$ & $85.5 \pm 5.6^{*}$ & 0.002 \\
\hline FR (cycle/mn) & $21.5 \pm 3$ & $21.7 \pm 2.4$ & $20 \pm 3.5$ & $18.9 \pm 2.7$ & 0.063 \\
\hline FEV $(\%)$ & $61.5 \pm 2.8^{*}$ & $61.1 \pm 2.7^{*}$ & $64.9 \pm 3.1^{*}$ & $65 \pm 2.1 *$ & 0.000 \\
\hline $\mathrm{TF}(\%)$ & $32.2 \pm 1.8$ & $33.2 \pm 2.7$ & $27.2 \pm 1.5$ & $29.3 \pm 2.7$ & 0.079 \\
\hline VF (\%) & $16.6 \pm 2.3^{*}$ & $17.4 \pm 3.2^{*}$ & $11.1 \pm 2.5^{*}$ & $14.1 \pm 3.1^{*}$ & 0.000 \\
\hline Muscle (\%) & $15.6 \pm 2.7^{*}$ & $15.6 \pm 3.3^{*}$ & $19.4 \pm 4.1^{*}$ & $17.1 \pm 2.1 *$ & 0.005 \\
\hline
\end{tabular}

WC: waist circumference ; BMI: body mass index; HR: heart rate; FR: frequency respiratory; FEV: forced expiratory volume; TF: total fat; VF: visceral fat; : $\mathrm{p}<0,05$ : significant 
traction of oxygen at the muscular level. The muscular architecture is modified with the possibility of significant increase in slow-twitch fibers during a specific endurance training $(12,13)$.

With respect to obese subjects, we noted that after the intervention program, they significantly modified their waist circumference, respiratory rate, forced expiratory volume per second, visceral fat, while no statistical difference was found for weight, body mass index, heart rate, total fat and muscle.

This study reveals overweight subjects have significantly improved after the program, their waist circumference, body mass index, heart rate, visceral fat, muscle versus obese subjects.

Our results are in line with the literature, which reports that physical activity limits the loss of muscle mass conventionally observed during energy restrictions. Thus, regular physical activity also helps to sustain weight loss achieved during dietary restriction, maintaining muscle mass and increasing daily energy expenditure $(15,16)$. Our results are superior to the latter because we have associated the practice of physical exercises with nutrition education.

Regular physical activity may help to reduce the pro-inflammatory status frequently encountered in the presence of obesity, especially abdominal, and contribute to accelerate atherosclerosis $(17,18)$. These findings corroborate our as have also shown a significant reduction in abdominal fat.

\section{CONCLUSION}

The results obtained demonstrate that the regular practice of aerobic endurance and muscle building exercises improve body composition in the direction of decrease in fat mass and increase in muscle mass, morphological parameters by a decrease in weight and physiological parameters by decreasing the resting heart and respiratory rate, and an improvement in respiratory capacity. However, these improvements were more noticeable in these overweight subjects than in the obese subjects.

\section{DECLARATION OF INTEREST}

The autors declare that there are no conflicts of interests.

\section{Acknowledgment}

Our thanks go to the authorities of the Lukunga Sports Club who accepted the realization of this study within the framework of this study, to all the staff of the medical fitness laboratory and the functional exercise of the University of the Universities for their contribution and to the parents who accepted the participation of their children to this study.

\section{Licensing}

This work is licensed under a Creative Commons Attribution 4.0 International (CC BY 4.0) License.

\title{
Sažetak
}

\section{PROCENA PROGRAMA FIZIČKE AKTIVNOSTI ADAPTIRANE PREMA MORFOLOŠKIM, FIZIOLOŠKIM KAO I PARAMETRIMA SASTAVA TELA KOD ADOLESCENATA SA POVEĆANOM TELESNOM MASOM I GOJAZNIH ADOLESCENATA, SPORTSKOG KLUBA,LUKUNG“ KINŠASA, U DEMOKRATSKOJ REPUBLICI KONGO}

\author{
Bofosa Linkoko Teddy, ${ }^{1}$ Kampy Kam Eric, ${ }^{2}$ Mabenza Miangindula Betty, \\ Kampend Njimbu Francois, ${ }^{2}$ Ekisawa Nkiama Constant ${ }^{1}$ \\ ${ }_{1}$ Kinesiology service, Physical medicine and rehabilitation, University clinics of Kinshasa, \\ University of Kinshasa, Democratic republic of Congo \\ ${ }^{2}$ Physiotherapy service, Physical medicine and rehabilitation, University clinics of Kinshasa, \\ University of Kinshasa, Democratic republic of Cong
}

Cilj rada bio je da se ispitaju efekti redovne fizičke aktivnosti na morfološke, fiziološke parametre, kao i na telesnu kompoziciju kod gojaznih i adolescenata sa povećanom telesnom masom. Metode: Eksperimentalna studija izvedena je na 30 adolescenata koji su razvrstani prema indeksu telesne mase (BMI) u dve grupe. Grupu 1 činili su adolescenti sa povišenom telesnom masom, BMI $25-22,9 \mathrm{~kg} / \mathrm{m}^{2}$, a grupu 2 činili su gojazni adolescenti sa
BMI $\geq 30 \mathrm{~kg} / \mathrm{m}^{2}$ koji su bili podvrgnuti programu adaptirane fizičke aktivnosti koja je povezana sa niskokalorijskom ishranom. Niskokalorijska ishrana podrazumevala je edukaciju o niskom nivou holesterola kao i niskom nivou zasićenih masnih kiselina (loše masne kiseline), ishrane bogate povrćem, voćem i vitaminima. Ovaj režim ishrane trajao je 6 meseci. Rezultati: Ova studija je pokazala da se nakon šest meseci ovakvog načina života, kod 
adolescenata sa povišenom telesnom, značajno smanjio obim struka ( $82,9 \pm 4,2 \mathrm{~cm}$ pre vs. $77,6 \pm 4,6 \mathrm{~cm}$ nakon), srčana frekvenca $(86,8 \pm 3,6$ srčana ciklusa/min pre vs. $81,4 \pm 3,8$ srčana ciklusa/min nakon), ukupna masnoća (32,2 $\pm 1,8 \%$ pre vs. $27,2 \pm 1,5 \%$ nakon), visceralna masnoća $(16,6 \pm 2,3 \%$ pre vs. $11,1 \pm 2,5 \%$ nakon $)$, i smanjenje mišićne mase $(15,6 \pm 2,7 \%$ pre vs. $19,4 \pm 4,1 \%$ nakon), dok se u grupi gojaznih adolescenata značajno smanjio obim struka $(88,9 \pm 6,2 \mathrm{~cm}$ pre vs. $85,8 \pm 5,9 \mathrm{~cm}$ nakon), visceralna masnoća $(17,4 \pm 3,2 \%$ pre vs. $14,1 \pm$ $3,1 \%$ nakon), respiratorni kapacitet $(61.1 \pm 2.7 \%$ pre vs. $65 \pm 2.1 \%$ nakon). Štaviše, ova studija je pokazala da adolescenti sa povišenom telesnom masom u poređenju sa gojaznim adolescentima više menjaju sledeće parameter: obim struka $(77,6 \pm 4,6 \mathrm{~cm}$ za osobe sa povećanom

\section{REFERENCES}

1. de Onis M, Onyango AW, Borghi E, Siyam A, Nishida C, Siekmann J.. Development of WHO growth references for school-aged children and adolescent. Bull Wold Health Organ. 2007; 85(9): 660-7.

2. Verdot C, Torres M, Salanave B, Deschamps V. Corpulence des enfants et des adultes en France metropolitaine en 2015. Résultats de l'étude Esteban et évolution depuis2006. Bull Epidemiol Hebd. 2017; (13): 234-41.

3. Lagger G, Chevalley $\mathrm{CH}$, Moutet AL, Sittarame F, Delétraz M, Chambouleyron M et al. L'education therapeutique du patient : une tension entre alliance therapeutique et techniques pedagogiques. Medecine des maladies Metaboliques. 2017; 11: 72-6.

4. O’Donnell JE, Foskett-Tharby R, Gill PS. General practice views of managing childhood obesity in primary care: a qualitative analysis. JRSM Open. 2017; 8(6): 205427041769396.

5. Bieleli E, Moswa JL, Ditu M, Kandjungu K, Mulumba M. Prévalence du diabPte sucré au sein de la population de Kinshasa. Congo Médical. 2000; 2(15): 1055-61.

6. Longo-mbenza B, Tonduangu K, Muyeno K, Phanzu M, Kebolo Baku A, Muvova D et al. Predictors of stroke-associated mortality in Africans. Rev Epidem Santé Publique. 2000; 48(1): 31-9.

7. Bakielukila E. Activité physique adaptée et prise en charge des élPves pubPres scolarisés de Kinshasa en surpoids et obPses. Mémoire de licence en médecine physique et de réadaptation, Faculté de Médecine, Université de Kinshasa. 2007.

8. Wilmore JH, Després JP, Stanforth PR, Mandel S, Rice $\mathrm{T}$, Gagnon J. Alterations in body weight and composition consequent to 20 wk of endurance training: the HERITAGE Family Study. Am J Clin Nutr. 1999; 70(3): 346-52.

9. Corte de Araujo AC, Roschel H, Picanco AR, do Prado DM, Villares SM, de Sa Pinto AL, et al. Similar health benefits of telesnom masom prema $85,8 \pm 5,9 \mathrm{~cm}$ za gojazne), indeks telesne mase $\left(24,9 \pm 4,1 \mathrm{~kg} / \mathrm{m}^{2}\right.$ za osobe sa povećanom telesnom masom vs. $28,8 \pm 1,2 \mathrm{~kg} / \mathrm{m}^{2}$ za gojazne), srčanu frekvencu $(81,4 \pm 3,8$ beat/min za osobe sa povećanom telesnom masom vs. $28,8 \pm 1,2$ beat/min za gojazne), visceralnu masnoću $(11,1 \pm 2,5 \%$ za osobe sa povećanom telesnom masom vs. $14,1 \pm 3,1 \%$ za gojazne) $\mathrm{i}$ mišiće $(19,4 \pm 4,1 \%$ za osobe sa povećanom telesnom masom vs. 17,1 $\pm 2,1 \%$ za gojazne). Zaključak: Kako gojazni adolescenti, tako i adolescenti sa povišenom telesnom masom nakon primenjenog režima ishrane i fizičke aktivnosti značajno su promenili svoje morfološke, fiziološke parametre kao i parametre telesnog sastava.

Ključne reči: adolescenti, telesni sastav, morfologija, fiziologija, povišena telesna masa, gojaznost.

endurance and high-intensity interval training in obese children. PLoS One. 2012; 7(8): e42747.

10. Bellows LL, Davies PL, Anderson J, Kennedy C. Effectiveness of a physical activity intervention for Head Start preschoolers: a randomized intervention study. Am J Occup Ther. 2013; 67(1): 28-36.

11. Kay SJ, Fiatarone Singh MA. The influence of physical activity on abdominal fat: a systematic review of the literature. Obes Rev. 2006; 7(2): 183-200.

12. Ekelund U, Franks PW, Sharp S, Brage S, Wareham $\mathrm{Nj}$. Increase in physical activity energy expenditure is associated with reduced metabolic risk independent of change in fatness and fitness. Diabetes Care. 2007; 30(8): 2101-6.

13. O'Donovan G, Thomas EL, McCarthy JP, Fitzpatrick J, Durighel G, Mehta S et al. Fat distribution in men of different waist girth, fitness level and exercise habit. Int J Obes (Lond). 2009; 33(12): 1356-62.

14. Royer TD, Martin PE. Manipulations of leg mass and moment of inertia: effects on energy cost of walking. Med Sci Sports Exerc. 2005; 37(4): 649-56.

15. De Bourdeaudhuij I, Van Cauwenberghe E, Spittaels H, Oppert JM, Rostami C, Brug J, et al. School-based interventions promoting both physical activity and healthy eating in Europe: a systematic review within the HOPE project. Obes Rev. 2011; 12(3)205-16.

16. Rocha VZ, Libby P. Obesity, inflammation, and atherosclerosis. Nat Rev Cardiol. 2009; 6(6): 399-409.

17. De Santé HA. Surpoids et obésité de l'enfant et de l'adolescent. Recommandations de bonne pratique clinique. Saint-Denis La Plaine: HAS. 2011. https://www.has-sante.fr/portail/upload/docs/application/pdf/2011-09/obesite_enfant_et_adolescent___argumentaire.pdf

18. Goujeon O. Les freins au depistage et B l'initiation de la prise en charge de l'obesite infantile: enquLte aupres des medecins generalistes de Maine-et-Loire [These d'exercice]. [France]: Universite d'Angers; 2016.

\section{Correspondence to/Autor za korespondenciju}

\section{Bofosa Linkoko Teddy}

14 luneko, Lemba township, Kinshasa/RD, Congo

Kinesiology service, Department of Physical Medicine and Rehabilitation, Faculty of Medicine, University Clinics of Kinshasa, University of Kinshasa, Democratic Republic of Congo email: bofosa.linkoko@unikin.ac.cd phone number: +243850143232 